\title{
Pembelajaran Berbasis Masalah: Pengoptimalan Media Online Melalui Pembelajaran Berjarak
}

\author{
Problem Based Learning: \\ Optimization Online Media Through Distance Learning \\ Heri Bayu Dwi Prabowo \\ Psikologi Pendidikan Islam, Pascasarjana, UIN Sunan Kalijaga Yogyakarta
}

\begin{tabular}{l}
\hline \hline ARTICLE INFO \\
Article history: \\
DOI: \\
10.30595/pssh.v1i.82 \\
Submitted: \\
April 12, 2021 \\
Accepted: \\
June 10, 2021 \\
Published: \\
June 14, 2021 \\
Keywords: \\
COVID-19 Pandemic, Problem \\
Based Learning, Distance \\
learning
\end{tabular}

\begin{abstract}
The world is being rocked by the covid-19 pandemic outbreak. The pandemic effect on all human activities as a whole, whitout exception the education world. Education as an one of the heart of the nation's solid survival must be save under these conditions, including education in Indonesia. Since the implementation of learning at home by the goverment on March, 16, 2020, learning patterns have changed in such a way. The question is, what kind of learning is effective in the present? In this case, the problem to be answered will be examined with the idea of distance learning (PJJ) through online media in an effort to keep the learning and learning process going. This research uses library research, while the source of data is obtained through a variety of relevant literature. In this case, the researcher uses theory of problem based learning and distance learning. As a result, the learning process at this time still needs to be intensively studied, improved and further developed. In addition, improving the format of education is a shared responsibility of all elements of society, working hand in hand and supporting the resilience and effectiveness of learning at all levels of education is a necessity.
\end{abstract}

This work is licensed under a Creative Commons Attribution 4.0 International License.

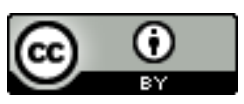

\section{Corresponding Author:}

Heri Bayu Dwi Prabowo

Psikologi Pendidikan Islam,

Pascasarjana, UIN Sunan Kalijaga Yogyakarta

Jalan Marsda Adisucipto, Yogyakarta, Indonesia

Email: herybdp@gmail.com

\section{PENDAHULUAN}

Dampak pandemi Covid-19 menjadikan pola pembelajaran berubah secara total. Pandemi ini bukanlah krisis kesehatan yang pertama kali terjadi di dunia. Laporan ABC News tertanggal 7 Maret 2020, menyatakan bawah proses penutupan sekolah telah terjadi di puluhan negara dunia, dikarenakan pandemi Covid-19 [1]. Banyaknya negara yang menetapkan kebijakan untuk menutup sekolah, berdampak pada proses belajar dan pembelajarn di sekolah, -biasanya dilakukan secara tatap muka- kini berubah menjadi daring atau dilakukan secara jarak jauh melalui media virtual. Sebagaimana laporan PBB, Organisasi Internasional yang bermarkas di New York, AS, menyebutkan bahwa jumlah siswa yang lebih dari 850 juta di dunia tidak bisa melaksanakan proses belajar di sekolah, dimana bidang pendidikan menjadi salah satu sektor yang terimbas dari Covid-19. Akibatnya, proses belajar dan pembelajaran menjadi terganggu dengan adanya kebijakan penutupan sekolah.

Demikian halnya di Indonesia, negara dengan jumlah sekolah banyak yang tersebar di berbagai daerah dari Sabang sampai Meraukae, menetapkan kebijakan untuk menutup sekolah serta menerapkan proses pembelajaran secara daring atau virtual. Langkah tersebut dilakukan dalam rangka pencegahan Covid-19, dan kebijakan tersebut muncul sebagai respons atas kebijakan pemerintah untuk merealisasikan program jaga jarak (social distance). Dengan 
kondisi yang demikian, diperlukan penekanan kepada pemerintah dengan seluruh jajarannya untuk menyiapkan segala antisipasi berbagai hal yang akan terjadi ke depan, diantaranya sektor pendidikan. Dimana salah satu kebijakannya adalah proses pembelajaran daring diberlakukan mulai hari Senin, 16-31 Maret 2020 [2].

Salah satu bentuk dari sekian banyak alternatif pembelajaran selama pandemi Covid-19 adalah sistim pembelajaran jarak jauh atau daring. Sedangkan pembelajaran daring itu sendiri merupakan proses pembelajaran dengan bantuan jaringan internet dan berbagai aksesbilitas tinggi, yang mana mempunyai kemampuan dalam memunculkan interaksi pembelajaran secara tatap muka di dunia maya [3]. Jadi, pembelajaran daring dapat dijadikan alternatif baru sebagai gantinya dari pembelajaran kelas tradisional.

Sistim pembelajaran daring tidak terlalu tinggi atau seefektif pembelajaran tradisional, terlebih dalam keadaan darurat seperti ini. Banyak persiapan yang harus diperhatikan agar pembelajaran dapat dilaksanakan secara maksimal, seperti infrastruktur untuk jaringan internet yang stabil. Oleh karenanya, dukungan dari pihak pemerintah sangatlah urgen. Pemerintah diharuskan untuk bersinergi dengan berbagai pihak dalam rangka memfasilitasi jaringan agar tersedia dengan baik.

Tentunya, dalam proses pembelajaran daring itu sendiri sangat membutuhkan berbagai dukungan perangkat mobile, seperti telepon seluler, jaringan, dan perangkat laptop dalam mengakses informasi sebaik mungkin. Di sisi lain, penggunaan perangkat mobile mempunyai kontribusi besar saat proses belajar dan pembelajaran, seperti halnya dalam mencapai tujuan pembelajaran meskipun dilakukan secara jarak jauh. Berbagai media pun dapat digunakan untuk mendukung proses pembelajaran secara daring [3]. Pembelajaran secara daring pun dapat dilakukan melalui beberapa media sosial, seperti Google Meet, Zoom, Facebook, Youtube dan Instagram.

Selain itu, sistim belajar dan pembelajaran daring tidaklah cukup hanya mempersiapkan jaringan mobile saja. Ada hal lain yang lebih utama dari itu, yakni kesiapan mental sumber daya manusianya (SDM = pendidik dan peserta didik), dua hal tersebut mutlak diperhatikan. Jadi, bermanfaat tidaknya infrastruktur yang telah memadai dengan fasilitas komplit sekalipun, akan menjadi tidak berarti jika para penggunanya (pendidik dan peserta didik) tidak siap untuk menjalankannya. Pada tahap persiapan SDM, sangat diperlukan sosialisasi pembelajaran daring secara masif, integritas dan terstruktur. Sebagai contohnya, melalui bentuk penyediaan sekaligus penyebaran video melalui media massa tentang buku panduan ataupun petunjuk dalam hal pedoman penggunaan teknologi yang tersedia.

Dalam kaitannya dengan penelitian yang akan dilakukan kali ini, dapat dibandingkan dengan penelitian yang dilakukan oleh Mohamad Dimyati, dkk, mengenai pemanfaatan teknologi sebagai media pembelajaran daring bagi guru dan siswa di SMK NU Rogojampi. Hasil penelitian menunjukkan bahwa kegiatan pelatihan pembelajaran daring baru dapat dilaksanakan melalui beberapa tahapan berupa analisis kebutuhan, penyiapan media, dan pelaksanaan kegiatan pembelajaran daring [4]. Di sisi lain, pelatihan haruslah berkelanjutan secara bertahap dan terkontrol, tidak hanya dilaksanakan dalam satu kali pertemuan.

C.L. Dillon dan C.N. Gunawardena dalam Rajab, menjelaskan tiga hal yang dapat menentukan keefektivitasan pembelajaran daring. Pertama, aspek teknologi, dimana peserta didik harus memiliki akses jaringan yang mudah dan efektif dalam penggunaannya. Kedua, aspek karakteristik pendidik, yakni pendidik berperan penting dalam pembelajaran daring. Dan Ketiga, aspek karakteristik peserta didiknya sendiri [2].

Berdasarkan gambaran tersebut, pembelajaran yang notabene berlangsung sepanjang hayat (long life education), haruslah tetap berjalan sebagaimana mestinya. Berlajar dan pembelajaran tidaklah mesti dilaksanakan secara tatap muka, dengan mengkondisikan suasana sedemikian rupa, proses belajar dan pembelajaran harus terus dilakukan, meski ditengah berbagai kendala pandemi Covid-19. Terdapat sejumlah variasi strategi pembelajaran yang ada, seperti halnya problem based learning (PBL) atau pembelajaran berbasis masalah. Model pembelajaran PBL dengan basis pemecahan masalah secara konkrit, menghendaki kesiapsiagaan serta kontekstualisasi masalah bagi peserta didik. Oleh karena itu, tujuan artikel ini diarahkan untuk menelaah lebih jauh keterkaitannya konsep penggunaan media daring melalui pembelajaran jarak jauh dengan strategi problem based learning (pembelajaran berbasis masalah).

\section{METODE PENELITIAN}

Penelitian artikel ini merupakan jenis penelitian literatur, sumber data diperoleh melalui referensi rujukan berupa buku, internet, artikel, dan jurnal. Penelitian ini berusaha menggali data dari berbagai bahan kepustakaan yang relevan dengan penelitian. Jika ditinjau dari tempat penelitian, maka penelitian kali ini termasuk studi pustaka, dimana penelitiannya dilakukan dengan cara menemukan sampai pada mengutip berbagai konsep literatur yang ada [5]. Data yang dikumpulkan berupa kata dan perbuatan manusia pada umumnya ataupun kelompok sosial [6], menggunakan metode sosial untuk mengeksplor dan mendalami makna yang ditinjau dari permasalahan sosial dan kemanusiaan [7].

\section{HASIL DAN PEMBAHASAN Problem Based Learning (PBL)}

Problem Based Learning (PBL) disebut-sebut sebagai model pembelajaran unik sekaligus menyenangkan, serta mampu meningkatkan keterampilan peserta didik di era sekarang ini. Dimana model pembelajaran PBL pertama kali dikembangkan oleh tokoh kenamaan Howard B pada tahun 1970 an di McMaster University Canada [8]. 
Pembelajaran dengan model PBL sendiri berdasarkan pada corak pemikir pendidikan di era 1923-1938, yakni filsuf John Dewey. Menurutnya, pembelajaran dengan model PBL bertujuan untuk menekankan aspek pentingnya sebuah pembelajaran melalui pengalaman peserta didik, sehingga apa yang dialami oleh peserta didik dapat tereksplorasi secara baik bagi mereka [9].

Sedangkan keterampilan peserta didik yang dimaksud berkisar pada aspek penalaran, koneksi dan komunikasi. Pada model pembelajaran PBL, peserta didik difokuskan untuk mempertajam daya berpikirnya melalui proses pembelajaran, dengan disajikan sebuah permasalahan nyata yang harus diselesaikan melalui berbagai macam penyelidikan oleh peserta didik secara berkelompok. Pada intinya, model pembelajaran PBL menghendaki penggunaan berbagai jenis kecerdasan peserta didik untuk melakukan proses pemecahan terhadap tantangan kehidupan sehari-hari, terlebih ketika peserta didik berhadapan dengan hal baru yang lebih kompleks.

Selanjutnya, model pembelajaran PBL berupaya untuk mendorong peserta didik agar menjalani proses pembelajaran secara kooperatif dalam skala kecil, sekaligus mendapatkan solusi pemecahan masalah; berfikir secara kritis-analitis; dan peserta didik mampu menetapkan sekaligus menggunakan fasilitas pembelajaran sesuai kebutuhannya [10]. Singkatnya, model pembelajaran ini menempatkan guru sebagai fasilitator dalam peranannya untuk menyajikan permasalahan, memfasilitasi proses penyelidikan masalah dan memonitoring interaksi antar peserta didik (student teaching learning).

Dapat diklasifikasikan bahwa model pembelajaran PBL akan mudah terlaksana jika guru mempunyai kesiapan dengan segala perangkat pembelajaran yang diperlukan. Begitupun peserta didiknya telah memahami proses pembelajaran, dan telah membentuk kelompok berskala kecil [11]. Umumnya, setiap kelompok -yang telah terbentuk- akan menjalankan proses pembelajaran melalui tujuh langkah pembelajaran berikut ini:

Pertama, menyusun beberapa istilah dan konsep tertentu ke dalam beberapa poin pengklasifikasian sesuai kebutuhan. Kemudian, masing-masing anggota kelompok diharuskan untuk mengerti terkait istilah dan konsep tersebut. Langkah pertama ini bertujuan untuk menyatukan cara pandang terhadap topik bahasan bagi masing-masing anggota kelompok. Kedua, Menyusun dan menentukan permasalahan. Variabel yang terdapat dalam masalah harus dijelaskan hubungan dan atau keterkaitan antar variabel tersebut. Ketiga, Menganalisa dan mengkritisi permasalahan. Masing-masing anggota kelompok menyampaikan gagasan (brainstorming) terkait masalah dengan fenomena sekarang dan konsep ideal mereka masing-masing.

Keempat, Menyatukan dan mengklasifikasikan gagasan yang telah dilontarkan masing-masing anggota kelompok, untuk kemudian dibuat konsep dengan memilah satu sama lain ke dalam beberapa poin pembahasan. Kelima, Merumuskan tujuan belajar. Kesepakatan dari anggota kelompok untuk merumuskan tujuan belajar yang akan dilaksanakan dengan menimbang pengetahuan mana yang belum jelas dan yang sudah jelas. Dalam hal ini, tujuan pembelajaran harus disesuaikan dan mempunyai keterkaitan dengan topik yang akan dibahas. Keenam, Setelah anggota kelompok mengetahui pengetahuan dan atau informasi mana yang belum diketahui, serta sudah ditetapkan tujuan belajar yang akan dilaksanakan, maka langkah selanjutnya adalah mengumpulkan sumber informasi lain yang akan mendukung proses belajar ke depan, dan Ketujuh, Mengkaitkan, menyatukan serta menguji dari hasil informasi baru yang diperoleh dengan topik bahasan, kemudian membuat laporan sebagai langkah terakhir.

\section{Media Daring}

Penggunaan media dan teknologi pada bidang pendidian tidak dapat dipisahkan ketika proses pembelajaran berlangsung. Jika corak pembelajaran konvensional (klasikal, seperti halnya ceramah yang monoton) membutuhkan tempat untuk melaksanakan pembelajaran, maka hal ini dirasa kurang untuk meningkatkan kompentensi peserta didik. Terlebih, jika proses belajar dan pembelajaran diakukan dengan cara diskusi, dan penyampaian materi pada corak pembelajaran konvensional mengharuskan pendidik dan peserta didik berada di tempat dan waktu yang sama. Oleh karena itu, media dan teknologi sebagai alternatif pendukung pembelajaran untuk memudahkan dan mendukung berkembangnya kompetensi peserta didik sangatlah urgen untuk diperhatikan.

Sistim pembelajaran secara daring merupakan tawaran dalam pemanfaatan media dan teknologi untuk mendukung dan memaksimalkan proses pembelajaran [4]. Pembelajaran daring pun dinilai mampu memudahkan pendidik dalam menyampaikan bahan ajarnya, dan memudahkan dalam melaksanakan diskusi kapan pun melalui media terkait. Jadi, pembelajaran daring ini melibatkan pendidik dan peserta didik ketika proses belajar dan pembelajaran berlangsung, dalam proses pembelajarannya, peserta didik dibimbing dan difasilitasi secara daring oleh guru. Di sisi lain, memudahkan peserta didik untuk mengunduh materi belajar dan berdiskusi seputar materi pelajaran. Alhasil, pembelajaran daring mampu untuk meningkatkan pengetahuan dan wawasan peserta didik [12].

\section{Optimalisasi Pembelajaran Jarak Jauh (PJJ)}

Peran teknologi dan informasi di era sekarang sangatlah berpengaruh dalam segala lini kehidupan, terkhusus pada bidang pendidikan dari segi pembelajarannya. Adapun terjadinya pengembangan berbagai aplikasi pendukung dalam proses pembelajaran adalah momentum yang tepat dalam menghadirkan model pembelajaran daring, hal ini sejalan dengan amanat pendayagunaan TIK dalam Renstra Kemendikbud tahun 2012 [13]. Dengan pemberdayaan jaringan internet yang berkolaboratif dengan pembelajaran sehingga mampu diakses secara luas kapan pun dan dimana 
pun, memungkinkan kehadiran internet sebagai layanan peningkat proses belajar dan pembelajaran. Salah satu solusinya berupa pembelajaran daring berbasis jarak jauh (PJJ), dimana pembelajaran dilakukan secara langsung dan bersamaan meskipun antar pendidik dan peserta didik terpaut oleh jarak. Secara historis, pendidikan dengan jarak jauh pertama kali dilaksanakan pada 20 maret 1728 oleh Kaleb Philips yang termaktub dalam salah satu iklan berita di luar negeri [14].

a. Payung Hukum Pembelajaran Jarak Jauh (PJJ)

Merujuk pada UU Pemerintah No. 20 Thn. 2003 tentang Sistim Pendidikan Nasional [15], menyatakan bahwa proses pembelajaran jarak jauh diartikan dengan proses pembelajaran dimana pendidik terpisah dari peserta didik, dan proses pembelajarannya dengan memanfaatkan berbagai sumber belajar melalui teknologi terkait. Adapun hadirnya UU tersebut erat kaitannya dengan permasalahan pendidikan di Indonesia, yakni menyangkut sistim pembelajaran yang kurang mendukung, begitu pula ditinjau dari metode pembelajaran, penggunaan media pembelajaran, dan bahan pembelajaran yang kurang tepat dalam hal penggunaan. Lebih lanjut, diterangkan dalam UU Pendidikan Tinggi, bahwa pembelajaran jarak jauh merupakan bagian dari penyelenggaraan pendidikan tinggi, sebagai bagian yang tidak terpisahkan dari penyelenggaraan pendidikan nasional [16]. Ciri khusus dalam pendidikan jarak jauh adalah keterpisahan antara pendidik dan peserta didik, fokus pelaksanaannya lebih ke metode pembelajaran dengan teknologi pendukung, melalui berbagai jenis variasi penggunaan media dan teknologi yang ada. Sedangkan tujuan pebelajaran jarak jauh yakni memungkinkan tersampaikannya informasi pembelajaran kepada peserta didik, yang mana tidak hadir secara fisik sebagaimana dalam sistim pembelajaran tradisional.

b. Pembelajaran Jarak Jauh (Daring / E-learning)

Melalui pembelajaran jarak jauh yang sedang digalakkan oleh pemerintah, poin yang mestinya menjadi pertimbangan adalah pemilihan media yang sesuai dengan proses belajar dan pembelajaran. Penyediaan media haruslah menjadi salah satu kinerja pemerintah dan berbagai lembaga terkait dengan pendidikan. Terlebih, ketika melibat perkembangan zaman saat ini, tentunya menjadi tuntutan yang merupakan kebutuhan bagi setiap individu, dengan cara apapun untuk memperoleh akses jaringan informasi secara mudah dan mampu berkomunikasi dengan cepat dan efisien.

Dikarenakan kebutuhan PJJ erat kaitannya dengan pertukaran informasi dan komunikasi antara pelaku PJJ, maka internet hadir sebagai salah satu media pilihannya. Internet mampu berperan untuk menyediakan berbagai macam informasi yang dibutuhkan dalam bidang apapun. Dengan kemampuannya untuk berkomunikasi tatap muka dan pengelolaan informasi, menjadikan internet sebagai media yang cocok untuk digunakan saat ini, terlebih dalam kapasitas keterjangkauannya serta membangun hubungan secara interaktif antara pelaku PJJ [17]. Sehingga, pemanfaatan internet untuk proses pembelajaran mulai ramai diminati, maka terbentuklah sistim pembelajaran $e$ learning.

E-learning didefinisikan sebagai sebuah sistim ataupun konsep pembelajaran yang memanfaatkan teknologi dan informasi dalam proses pembelajarannya. Pembelajaran melalui e-learning bertujuan untuk memudahkan pembelajaran dengan menggunakan sistim elektronik [18]. Dan, e-learning pun berusaha menyatukan berbagai prinsip proses pembelajaran dengan berbasis teknologi, dimana sistim pembelajarannya dilaksanakan dengan tatap muka secara langsung di ruang virtual, tidak sebagaimana pembelajaran tradisional.

Perlu diperhatikan, dalam e-learning, konten merupakan perihal yang paling utama sebagai titik acuan berhasil atau tidaknya proses belajar dan pembelajaran. Selalin konten, interaksi antar pengguna juga sangat diperhatikan sebagai pengganti proses tatap muka. Permasalahan yang muncul, walaupun konten atau bahan ajar yang ada di internet dapat berupa teks serta presentasi, namun konten teks dirasa masih kurang dalam memenuhi kebutuhan belajar peserta didik. Di sisi lain, konten yang banyak digunakan dalam bentuk teks atau slide presentasi kurang begitu interaktif, sehingga berdampak pada beberapa mata pelajaran tertentu, khususnya mata pelajaran yang bersifat praktikum akan lebih sulit lagi untuk tersampaikan.

\section{c. Komponen Pembelajaran Daring atau E-learning}

Menurut Wahono [17], berbagai komponen yang terdapat dalam e-learning meliputi:

1) Infrastruktur pendukung. Infrastruktur tersebut meliputi PC (personal computer), jaringan pada komputer, internet dan berbagai perlengkapan multimedia.

2) Sistim dan aplikasi. Sistim dari prangkat lunak yang dapat memvisualisasi proses pembelajaran konvensional. Yakni seputar bagaimana cara memanajemen kelas daring, membuat konten materi, forum untuk diskusi, sistim penilaian (rapot), sisitim ujian secara daring, dan berbagai fitur lain yang berhubungan dengan manajemen proses pembelajaran daring. Sistim perangkat lunak itu disebut juga dengan Learning Management System $(L M S)$. Dimana LMS banyak yang bersifat opensource, sehingga dapat dimanfaatkan secara mudah dan murah untuk digunakan di berbagai macam sekolah, dan

3) Konten. Yakni bahan ajar dan konten yang terdapat pada e-learning system (Learning Management System). Bahan ajar dan konten berbentuk Multimedia-based Content (berbentuk multimedia interaktif) atau Text-based 
Content (konten berbentuk semacam buku pelajaran). Biasanya tersimpan dalam Learning Management System $(L M S)$, sehinga peserta didik dapat menjalankannya kapan pun dan di mana pun.

d. Cara Pembelajaran Jarak Jauh (PJJ)

Melalui Peraturan Menteri Pendidikan dan Kebudayaan No. 109 Thn. 2013, Pasal 7 yang menyatakan bahwa proses pembelajaran secara jarak jauh dan atau mandiri yakni:

1) Sistim pembelajaran yang mana pendidik dan peserta didik saling terpisah.

2) Menekankan belajar mandiri, terstruktur, dan sekaligus terbimbing dengan menggunakan berbagai macam sumber belajar pendukung.

3) Memanfaatkan berbagai sumber belajar, yang mana tidak mengharuskan untuk berada pada satu tempat sama dengan peserta didik.

4) Menggunakan bahan ajar pembelajaran berbentuk elektronik, yang dikombinasikan dengan bahan ajar lain dalam berbagai variasi bentuk, format, media, dan sumbernya.

5) Memanfaatkan media pembelajaran berbasis pada teknologi, informasi serta komunikasi sebagai sumber belajar yang mudah untuk diakses kapan pun dan di mana pun, dan

6) Memaksimalkan pola interaksi pembelajaran berbasis teknologi, informasi serta komunikasi meskipun dimungkinkan untuk melakukan pembelajaran secara konvensional [16].

e. Contoh Aplikasi Pembelajaran Jarak Jauh (PJJ)

Pembelajaran model jarak jauh sangat bergantung pada jenis media yang dipakai. Kita sepakat bahwasannya penggunaan media pada sistim pembelajaran jarak jauh sangatlah bervariasi. Media tersebut bisa berupa bahan cetak, gelombang frekuensi seperti radio, gelombang visual berupa televisi, dan campuran berbagai gelombang seperti komputer, video interaktif, dan teknologi multimedia komputer.

Satu diantara teknologi dalam pembelajaran yang dapat digunakan yakni pembelajaran berbasis android, dimana pendidik dan peserta didik dapat menggunakan fasilitas yang tertera di dalamnya. Dengan android, pendidik dan peserta didik dapat mengakses aplikasi untuk proses belajar dan pembelajarannya di play store, semisal google class. Aplikasi ini dapat digunakan untuk sistim pembelajaran daring, dimana hampir seluruh pendidik dan peserta didik mempunyai fasilitas android untuk mengunduhnya [19].

f. Hasil Pembelajaran Jarak Jauh (PJJ)

Dari pembahasan pembelajaran jarak jauh (PJJ), Hanson sdan Maushak dalam penelitiannya menyimpulkan bahwa pembelajaran jarak jauh relatif lebih efektif dibandingkan dengan pendidikan gaya tradisional. Sama halnya dengan penelitian Arbaugh dan Stelzer, bahwa gaya berlajar berbasis web (PJJ) lebih dapat mengatasi permasalahan perbedaan belajar daripada pembelajaran gaya tradisional. Pun demikian, berbagai penelitian yang dilakukan banyak pihak justru cenderung lebih mendukung pembelajaran daring daripada pembelajaran tradisional [20].

g. Refleksi Pembelajaran Jarak Jauh (PJJ)

Secara umum, mengoptimalkan pembelajaran jarak jauh (PJJ) dengan metode pembelajaran berbasis masalah (PBL) masih terus dievaluasi. Sebagaimana dinyatakan oleh Nurul Yaqin, bahwa ada beberapa evaluasi yang menjadi catatan dalam pembelajaran daring [21]. Pertama, ketidakmerataan siswa dalam memiliki gadget; kedua, kompetensi guru dalam pembelajaran daring; ketiga, implementasi pembelajaran daring secara mendadak; keempat, tidak semua guru dan peserta didik memiliki kuota internet; dan kelima, perlunya pengawasan dari orang tua. Alhasil, banyak peserta didik yang lalai, mereka cenderung bermain, santai, dan tidak serius mengikuti program pembelajaran secara daring.

Melihat berbagai kendala yang muncul, maka diperlukan sinergitas dari berbagai pihak untuk mendukung sistem pembelajaran yang ada. Hal tersebut akan terealisasi sebagaimana yang diharapkan apabila masing-masing pihak memahami peran dan fungsinya masing-masing. Oleh karena itu, pembelajaran daring dengan metode berbasis masalah, akan menjadi efektif diterapkan bilamana seluruh lapisan masyarakat saling bahu-membahu dalam proses pelaksanaannya.

Adapun bagi pendidik, dilarang untuk gaptek (gagal teknologi atau tidak tahu-menahu tentang teknologi). Pendidik harus mampu mengoperasikan teknologi untuk mendukung pembelajaran secara daring, mampu bervariasi dalam pemilihan dan penggunaan media pembelajaran daring yang sesuai. Sedangkan bagi pemerintah, haruslah partisipatif dalam mencanangkan berbagai program pelatihan pembelajaran secara daring, baik untuk pendidik maupun peserta didik, disamping menyediakan platform media secara gratis untuk mendukungnya. Bagi orang tua peserta didik, harus dapat memposisikan diri sebagai fasilitator dan memonitoring bagi anaknya selama proses pembelajaran. Terakhir, bagi berbagai lembaga swasta yang berkecimpung dalam pendidikan haruslah mendukung secara aktif dengan menyediakan berbagai fasilitas yang dibutuhkan, seperti pemberian kuota gratis, penyediaan aplikasi pembelajaran yang mudah dan terjangkau, serta mendukung program pembelajaran dari segi mental maupun kesehatan sebagai penunjang bagi pendidik dan peserta didik. 


\section{KESIMPULAN}

Benang merah dari optimalisasi penggunaan media daring melalui pembelajaran jarak jauh berbasis pada pembelajaran berbasis masalah (problem based learning), masih perlu pengkajian secara intensif dan berkala, agar terus diperbaiki dan dikembangkan sesuai situasi-kondisi sekarang. Mengingat belajar dan pembelajaran adalah konsep kehidupan yang terus berlangsung sepanjang hayat, tidak memandang kondisi dan tempat, maka dari itu perbaikan sistim sekaligus proses belajar dan pembelajaran perlu ditingkatkan dan diperbaharui. Disamping itu, kondisi negara Indonesia yang sedang mengalami wabah pandemi Covid-19, ditambah dengan kesiapan sumber daya manusia untuk terus bertahan hidup, maka kiranya perlu untuk digalakkan tentang belajar dan pembelajaran yang sesuai dan memadai bagi pendidik dan peserta didik di seluruh tingkatan, terlebih menimbang aspek keefektifan dan efisiensi sistim belajar dan pembelajaran daring. Hal ini dapat terlaksana dengan baik jika berbagai elemen yang ada saling bahu-membahu, baik dari pemerintah, lembaga swasta maupun masyarakat secara umum.

\section{Ucapan Terima Kasih}

Penulis mengucapkan terima kasih kepada segenap keluarga besar Pascasarjana UIN Sunan Kalijaga atas dukungan moril selama penelitian. Terima kasih pula kepada berbagai pihak yang telah membantu, baik dari keluarga, teman satu kelas Psikologi Pendidikan Islam, Interdisciplinary Islamic Studies (IIS) dan juga para dosen pengampu mata kuliah di kampus.

\section{DAFTAR PUSTAKA}

[1] A. Purwanto, R. Pramono, M. Asbari, C. C. Hyun, L. M. Wijayanti, dan R. S. Putri, "Studi Eksploratif Dampak Pandemi COVID-19 Terhadap Proses Pembelajaran Online di Sekolah Dasar," EduPsyCouns: Journal of Education, Psychology and Counseling, vol. 2, no. 1, hlm. 1-12, 2020.

[2] M. Rajab, "Evaluasi dan Optimalisasi Pembelajaran Daring," detiknews. https://news.detik.com/kolom/d4960905/evaluasi-dan-optimalisasi-pembelajaran-daring (diakses Mei 17, 2020).

[3] F. Firman dan S. Rahayu, "Pembelajaran Online di Tengah Pandemi Covid-19," Indonesian Journal of Educational Science (IJES), vol. 2, no. 2, hlm. 81-89, 2020.

[4] D. Suwardiyanto dan H. Yuliandoko, "PEMANFAATAN TEKNOLOGI SEBAGAI MEDIA PEMBELAJARAN DARING (ON LINE) BAGI GURU DAN SISWA DI SMK NU ROGOJAMPI," JDinamika, vol. 2, no. 2, 2017.

[5] Widodo, Cerdik Menyusun Proposal Penelitian Skripsi, Tesis, dan Disertasi, 4 ed. Jakarta Timur: MAGNAScript Publishing, 2012.

[6] Afrizal, Metode penelitian kualitatif: sebuah upaya mendukung penggunaan penelitian kualitatif dalam berbagai disiplin ilmu. 2014.

[7] A. F. Rianayati Kusmini Pancasari, Penerj., Research Design: Pendekatan Metode Kualitatif, Kuantitatif, dan Campuran, 3 ed. Yogyakarta: Pustaka Pelajar, 2018.

[8] I. Istiatutik, "Penerapan Metode Problem Based Learning untuk Meningkatkan Hasil Belajar Pelajaran Ekonomi," Jurnal Pendidikan: Riset dan Konseptual, vol. 1, no. 1, hlm. 45-51, 2017.

[9] A. M. WARAULIA, "PENERAPAN METODE PROBLEM BASED LEARNING DAN MEDIA GAMBAR DALAM PEMBELAJARAN MEMBACA CERITA," Premiere Educandum: Jurnal Pendidikan Dasar dan Pembelajaran, vol. 6, no. 01, 2016.

[10] D. Sunardi dan N. Nelfiyanti, "PENERAPAN METODE PROBLEM BASED LEARNING DALAM MATAKULIAH AL-ISLAM II DI FAKULTAS TEKNIK UNIVERSITAS MUHAMMADIYAH JAKARTA," JISI: Jurnal Integrasi Sistem Industri, vol. 2, no. 2, hlm. 1-8, 2015.

[11] S. Saily, "Penerapan Metode Pembelajaran PBL (Problem Based Learning) Terhadap Hasil Belajar Peserta Didik," Akademika: Jurnal Keagamaan dan Pendidikan, vol. 15, no. 1, hlm. 46-61, 2019.

[12] E. Munastiwi, “ANALISIS IMPLEMENTASI MODEL PEMBELAJARAN MULTIMEDIA BERBASIS WEB TEHADAP MOTIVASI BELAJAR,” PROSIDING, hlm. 151.

[13] M. J. Fuady, "Pengembangan aplikasi evaluasi pembelajaran online untuk pendidikan jarak jauh," TEKNO, vol. 26, no. 2, 2017.

[14] M. E. Sulistyo, “JENIS-JENIS PEMBELAJARAN JARAK JAUH BERBASIS TEKNOLOGI INFORMASI UNTUK PARA PENGUSAHA,” Telematika: Jurnal Informatika dan Teknologi Informasi, vol. 9, no. 1, 2014.

[15] G. K. Putri dan Y. A. S. Dewi, "Pengaruh Model Pembelajaran Jarak Jauh Berbasis Google Classroom," $A L-$ FIKRAH: Jurnal Studi Ilmu Pendidikan dan Keislaman, vol. 2, no. 1, hlm. 60-79, 2019.

[16] E. Susanti, R. Harta, A. Karyana, dan M. Halimah, "Desain Video Pembelajaran yang Efektif pada Pendidikan Jarak Jauh: Studi di Universitas Terbuka,” Jurnal Pendidikan dan Kebudayaan, vol. 3, no. 2, hlm. 167-185.

[17] M. Agustina dan A. M. Bakti, "Tingkat Kesiapan E-learning (E-learning Readiness) universitas Bina Darma sebagai Media Pembelajaran Pendidikan Jarak Jauh,” Jurnal Ilmiah Matrik, vol. 17, no. 2, hlm. 123-132, 2015. 
[18] A. Cucus dan Y. Aprilinda, "Pengembangan E-Learning Berbasis Multimedia untuk Efektivitas Pembelajaran Jarak Jauh," Explore: Jurnal Sistem informasi dan telematika, vol. 7, no. 2, 2016.

[19] N. Septantiningtyas, "Pengaruh Pembelajaran Jarak Jauh Dengan Aplikasi Google Class Terhadap Hasil Belajar Mahasiswa," EDURELIGIA; JURNAL PENDIDIKAN AGAMA ISLAM, vol. 2, no. 2, hlm. 131-135, 2018.

[20] S. Suyantiningsih, "Integrasi Teamwork dan Kohesivitas Kelompok dalam Proses Pembelajaran Peserta Didik pada Pendidikan Jarak Jauh Online,” Majalah Ilmiah Pembelajaran, vol. 5, no. 1, 2009.

[21] "Optimalisasi Pembelajaran Daring - Kabar Madura." https://kabarmadura.id/optimalisasi-pembelajarandaring/ (diakses Jun 04, 2020). 